\title{
A Geometric Morphometric Analysis for Ranid Taxonomy: Chondrocranial Shape Variation of Five Ranid Species (Anura: Ranidae)
}

\author{
Ranid Taksonomisinde Geometrik Morfometrik Analiz: Beş Ranid \\ Türünün Kondrokranial Şekil Varyasyonu (Anura: Ranidae)
}

\author{
Research Article
}

Elif Yıldırım

Department of Biology, Faculty of Science, Dokuz Eylül University, i̇zmir, Turkey.

\section{A B S TR AC T}

\begin{abstract}
A landmark-based geometric morphometrics of the dorsal view of the chondrocranium was analysed for A 188 specimens to investigate the hypothesis of species shape and size differences among Rana tavasensis, $R$. macrocnemis, Pelophylax ridibundus, $P$. bedriagae and $P$. caralitanus. Canonical variate analysis (CVA) is applied to determine whether the shape and size differences in the chondrocranium of five ranids can be used to classify those at a taxonomic level. The result of CVA analysis shows that five ranid species examined here discriminate as mountain (Rana sp.) and water (Pelophylax sp.) frogs. In discriminant function analysis (DFA), each pair of species was analyzed and the results show that there is no interspecific shape difference among Pelophylax species. However, the interspecific shape variations in the cornua trabeculae, articular process of the palatoquadrate and processus muscularis quadrati, were present between Rana species ( $R$. macrocnemis and R. tavasensis).
\end{abstract}

Key Words

Geometric morphometrics, Rana, Pelophylax, chondrocranium.

\section{öz}

\begin{abstract}
ondrokraniumun dorsal görüntüsünün landmark işaretlemelerine dayalı geometrik morfometrik analizi, Rana tavasensis, R. macrocnemis, Pelophylax ridibundus, $P$. bedriagae ve $P$. caralitanus türlerinin arasındaki şekil ve boyut farklılıklarının hipotezini araştırmak için 188 örnekte analiz edildi. Kanonik varyans analizi beş ranid türünün şekil ve boyut farklılıklarının taksonomik seviyede sınıflandırmak için kullanılıp kullanılmayacağını belirlemek için uygulandı. Analiz sonucu gösterdi ki araştırılan beş ranid türü dağ (Rana sp.) ve su (Pelophylax sp.) kurbağaları olarak ayrıldı. Diskriminant analizinde, herbir tür çifti analizi edildi ve Pelophylax türleri arasında türlerarası bir farklılık gözlenmedi. Ancak, processus muscularis quadrati, palatokuadratın artikular process'i ve cornua trabeculae'daki türler arası şekilsel varyasyonlar Rana türleri ( $R$. macrocnemis and $R$. tavasensis) arasında bulunmuştur.
\end{abstract}

\section{Anahtar Kelimeler}

Geometrik morfometrik, Rana, Pelophylax, kondrokranium.

Article History: Received: May 9, 2018; Revised: Jun 26, 2018; Accepted: Jul 23, 2018; Available Online: Nov 13, 2018. DOI: 10.15671/HJBC.2018.262

Correspondence to: E. Yıldırım, Department of Biology, Faculty of Science, Dokuz Eylül University, İzmir, Turkey. 


\section{INTRODUCTION}

$T$ he he family Ranidae is one of the most diverse amphibian groups and contains 389 recognized species [1]. The taxonomy of this family has been investigated by several researchers [2-13]. However, there is still a gap in the literature about the shape change in the larval anuran chondrocranium. Although the use of geometric morphometrics in amphibian species has increased in recent years, detailed studies of geometric morphometrics in the larval anuran chondrocranium are received relatively limited attention [14-17]. Larson [15] described the interspecific variation of larval chondrocranial shape and allometry among six ranid species (Rana sylvatica, R. catesbeiana, R. calamitans, R. palustris, $R$. pipiens and $R$. sphenocephala).

Morphological studies have attracted much attention because of their use in definition of species $[15,18-20]$. Moreover, understanding the function of the morphological structures provides important data about the taxonomy, ecology and development of species. Taxonomy discriminate groups by using color patterns of species despite variations of the color patterns of species and bases greatly on morphology. Therefore, it may be sometimes problematic to describe species by relying on morphological features. Geometric morphometrics (GMM) is a technique that plays an important role in many biological studies. The most important advantage of GMM is to have comprehensive data about shape that is obtained from a set of landmarks [21]. Variations in body shape of species result in the ability that occupy habitats or reproduce successfully.

The genera Rana and Pelophylax are still unclear. Some researchers suggest that morphometric data cannot be used to identify $P$. ridibundus. They also suggest that the taxonomic status of $P$. bedriagae needs more studies [22]. Moreover, morphologies of five ranids are highly similar in their genus and generally, there are no differences on coloration and morphological patterns in these morphs. Ranids examined in this study mostly live in sympatry. It makes these genera as an ideal model for investigating morphometric differences.

To the best of our knowledge, this is the first study that addresses the chondrocranial shape variations of the five ranids. In this study we aimed to: 1) compare dorsal chondrocarnium of three ranid species from the genus Pelohylax and two ranid species from the genus Rana using geometric morphometrics to determine interspecific shape variation; 2) to evaluate chondrocranial shape pattern for intra- and interspecific taxonomy; 3 ) to consider the phylogenetic signal with the geometric morphometric analysis.

\section{MATERIALS and METHODS}

\section{Study Areas and Specimens Examined}

A total of 188 larvae of the five ranid species: Pelophylax bedriagae, P. ridibundus, P. caralitanus, Rana macrocnemis and $R$. tavasesnsis were obtained during fieldwork between 2013 and 2016. Information on Ranid species examined here is given in Table 1. Larvae were staged according to Gosner [23]. Clearing and double staining technique follows that of Wassersug [24]. All specimens measured in this study were deposited in ZDEU (Zoology Department Dokuz Eylül University) at Dokuz Eylül University.

\section{Landmark Selection}

A total of 10 landmarks based on Larson [14] were used for this study. Samples between

Table 1. List of specimens used in analysis.

\begin{tabular}{|c|c|c|c|}
\hline Species & Location & $\begin{array}{l}\text { Elevation } \\
(\mathrm{m})\end{array}$ & Date \\
\hline Pelophylax ridibundus & $\begin{array}{c}\text { Efteni Lake, Düzce, } \\
\text { Turkey }\end{array}$ & 118 & 15.04.2016 \\
\hline Pelophylax bedriagae & $\begin{array}{c}\text { Saklı Lake, Denizli, } \\
\text { Turkey }\end{array}$ & 960 & 10.04 .2015 \\
\hline Pelophylax caralitanus & $\begin{array}{c}\text { Işıklı Lake, Denizli, } \\
\text { Turkey }\end{array}$ & 818 & 31.05 .2015 \\
\hline Rana tavasensis & Tavas, Denizli, Turke & 1646 & 16.04 .2015 \\
\hline Rana macrocnemis & Uludağ, Bursa, Turkey & 2221 & 24.04 .2013 \\
\hline
\end{tabular}


Gosner Stages 26-40 were used for geometric morphometric analysis because of occurrence the remodeling of chondrocranium after Stage 40. Landmarks are described as follows:

1. Point of maximum curvature between the confluences of the cornua trabeculae.

2. Anteromedial corner of the cornua trabeculae.

3. Anterolateral corner of the cornua trabeculae.

4. Anteromedial corner of the articular process of the palatoquadrate.

5. Anterolateral corner of the articular process of the palatoquadrate.

6. Anteroventral margin of the processsus muscularis quadrati.

7. Posteroventral margin of the processsus muscularis quadrati.

8. Maximum posterior curvature of the otic capsule.

9. Maximum anterior curvature of the otic capsule.

10. Anterior attachment of the commissura quadratocranialis anterior to the braincase.

\section{Morphometric Analyses}

Dorsal view of chondrocranium of five ranids was photographed with Leica DFC295 with a digital camera. A total of 10 landmarks were digitized in 188 specimens in total. I used 33 specimens from Pelophylax bedriagae, 42 specimens from
$P$. caralitanus, 32 specimens from $P$. ridibundus, 45 specimens from Rana macronemis and 36 specimens from $R$. tavasensis for geometric morphometric analyses. These landmarks were digitized on right side of each dorsal chondrocranium in tpsDig (v.2.16; Rolf, 2010). MorphoJ (version 1.05d) software was used for characterizing the primary variations in dorsal chondrocranial shape among ranid species. We analyzed the shape differences of ranid species by using multivariate statistics (Canonical variance analysis (CVA), Principle component analysis (PCA) and Discriminant function analysis (DFA).

\section{RESULTS}

Principle component analysis displays variation among samples. The first four principle components (PC) explained $80.9 \%$ of the total variance in the data. PC 1 accounts for $34.37 \%$ of the variation and $P C 2$ for $31.39 \%$ of the variation. A plot of principle component 1 (PC1) against principle component 2 (PC2) explain $65.7 \%$ of the total variance. However, there were no clusters (Figure 1).

Canonical variance analysis (CVA) is a method used to display the shape variation that best differentiate among specimens. Procrustes distances were calculated by using a canonical

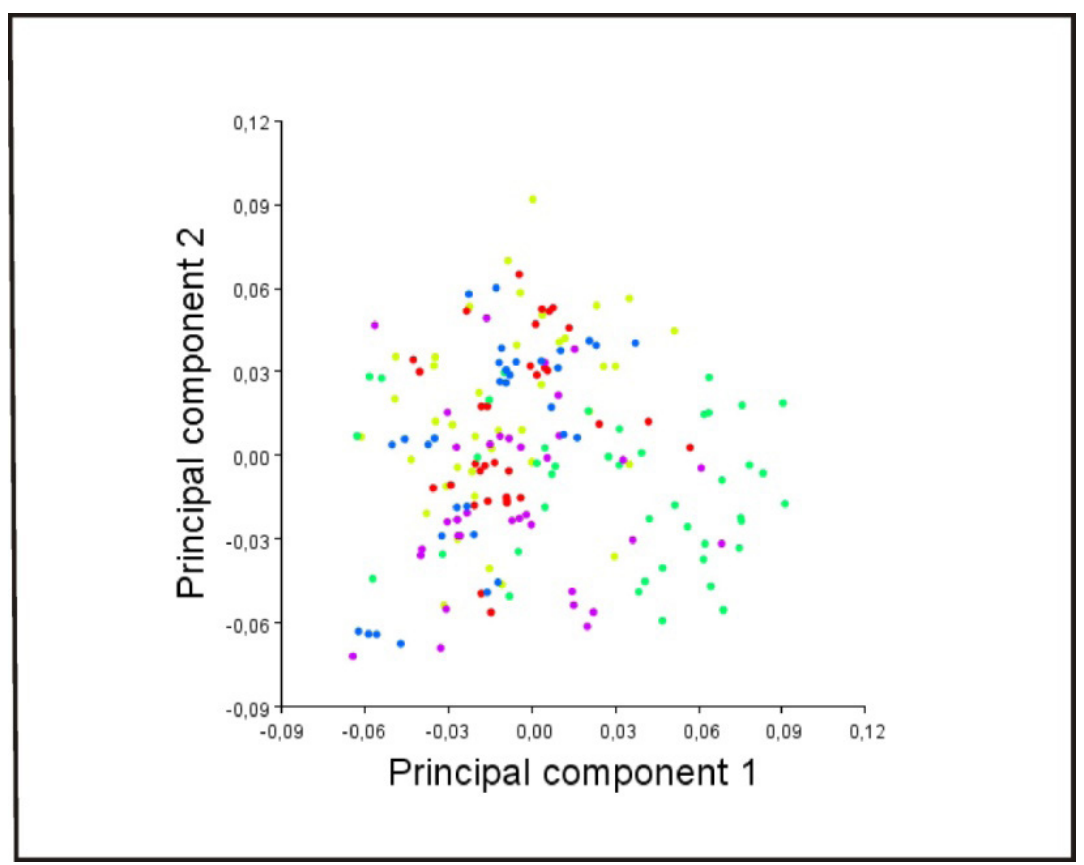

Figure 1. Scatter plot pf PCA in five ranids. 
variate analysis and contain a permutation test with 10000 iterations for testing shape variation of each species. Figure 2 displays deformation grids of ranids correlated with the canonical variate 1 (CV 1) and CV 2 and shows shape differences in the chondrocranium of five ranids. In CVA, the first two canonical variate (CV1) explain $85.8 \%$ of the total variance. The first four components explained 100\% of the variance. The scores of the two CVs for ranid species showed that specimens grouped into two distinct clusters while there was a high degree of overlap in Pelophylax species.

The first axis separates Rana sp. (Rana macrocnemis and $R$. tavasensis) from Pelophylax sp. (Pelohylax bedriagae, $P$. ridibundus and $P$. caralitanus) (Figure 2). Rana tavasensis and $R$. macrocnemis with a negative score on CV1 whereas
Pelohylax bedriagae, $P$. ridibundus and $P$. caralitanus have a positive score on the same CV.

Rana tavasensis with positive score on CV2, has laterally orientated the cornua trabeculae (Landmarks 1, 2 and 3), a larger the articular process (Landmars 4 and 5), a smaller the processuss muscularis quadrati (Landmarks 6 and 7) and a larger and more lateral oriented the otic capsule (Landmarks 8 and 9) (Figure 2A). Rana macrocnemis has negative score on $\mathrm{CV} 2$, possess a smaller the cornua trabeculae (Landmarks 1, 2 and 3), a longer the articular process (Landmarks 4 and 5), a larger the processuss muscularis quadrati (Landmarks 6 and 7) and more medial oriented and smaller the otic capsule (Landmarks 8 and 9) (Figure 2B). Rana species with negative scores on $\mathrm{CV} 1$, has more lateral orientated and
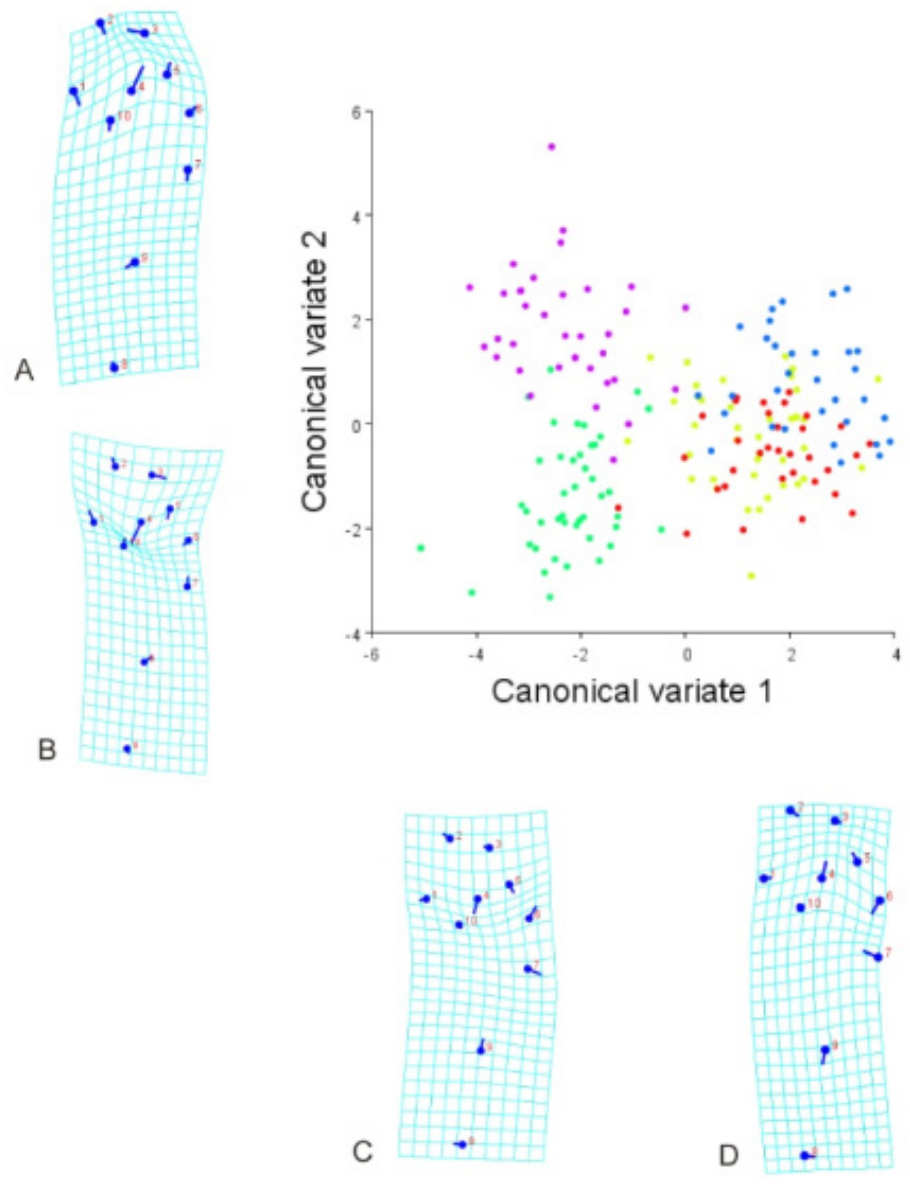

Figure 2. Scatter plot of CVA in five ranids (red: $P$. bedriagae, blue: $P$. ridibundus, yellow: $P$. caralitanus, green: $R$. macronemis and purple: $R$. tavasensis). A. positive curvature of landmarks on CV 2, B. negative curvature of landmarks on CV 2, C. negative curvature of landmarks on CV 1, D. positive curvature of landmarks on CV 1. 
smaller the cornua trabeculae (Landmarks 1, 2 and 3), more anterior orientation of the articular process (Landmarks 4 and 5), a smaller the processus muscularis quadrati (Landmarks 6 and 7) and more lateral oriented and smalller the otic capsule (Landmarks 8 and 9) (Figure 2C). Pelophylax bedriagae, $P$. ridibundus and $P$. caralitanus that have positive scores on CV1 possess more medial orientation of the cornua trabeculae (Landmarks 1, 2 and 3), more posterior orientated the articular process (Landmarks 4 and 5), a larger the processus muscularis quadrati (Landmarks 6 and 7) and more medial oriented and larger the otic capsule (Landmarks 8 and 9) (Figure 2D). Procrustes distances calculated for five ranid species. Pelophylax species have lower distances among themselves. First, $P$. caralitanus and $P$. bedriagae have a lower distance (0.019) than others do. Second, $P$. ridibundus and $P$. bedriagae show a lower distance (0.026). Finally, $P$. ridibundus and $P$. caralitanus exhibit a lower distance (=.027) than the remaining species. Also, Mahalanobis distances calculated among species is similar with the results of Procrustes distances (The lowest dinstance belongs to first $P$. caralitanus and $P$. bedriagae (2.31) and then $P$. ridibundus and $P$. bedriagae (2.48).

Discriminant function analysis (DFA) was used to perform distinct analyses for each pair of species. According to DFA, there were no interspecific shape differences among Pelophylax species (Figures 3A, B and C). However, the interspecific shape variations, which were caused by the cornua trabeculae, articular process of the palatoquadrate and processus muscularis
A

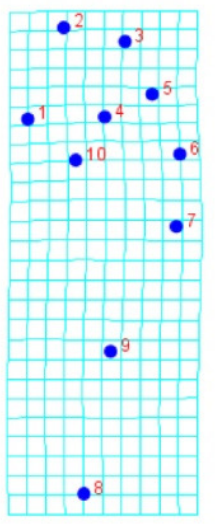

C

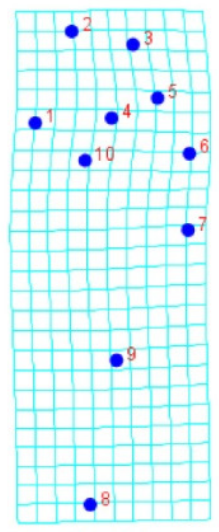

B

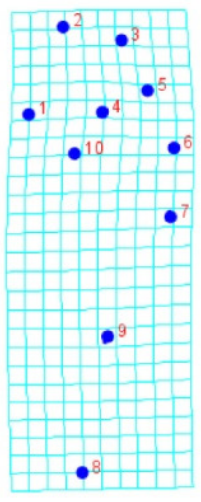

D

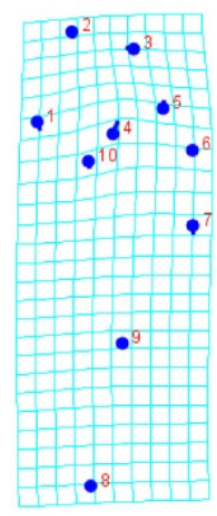

Figure 3. The results of DFA analysis. A. Pelophylax bedriagae-P. caralitanus, B. P. bedriagae-P. ridibundus, C. P. caralitanus-P. ridibundus, D. Rana macrocnemis- $R$. tavasensis. 
quadrati, were present between $R$. macrocnemis and $R$. tavasensis (Figure 3D). These differences were as follows: (1) the cornua trabeculae are shorter and located laterally, (2) the articular process of the palatoquadrate tends to be located more posteriorly and (3) the processus muscularis quadrati is smaller.

DFA shows that the shape variations existed between the genera Rana and Pelophylax. The shape differences between $P$. bedriagae and
R. macrocnemis were as follows: (1) more anteriorly located the articular process of the palatoquadrate, (2) more medial orientated and smaller the processus muscularis quadrati. Moreover, the shape variations were available between $P$. bedriagae and $R$. tavasensis. These were: (1) more laterally located the cornua trabeculae, (2) more medial orientated and smaller the processus muscularis quadrati and (3) more laterally orientated the otic capsule (Figures $4 A$ and $D$ ).
A

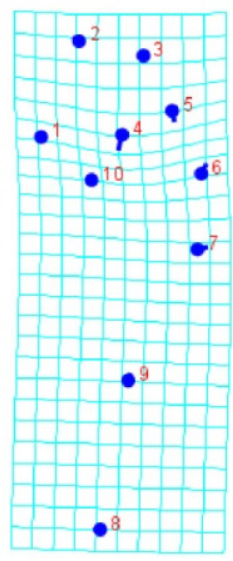

D

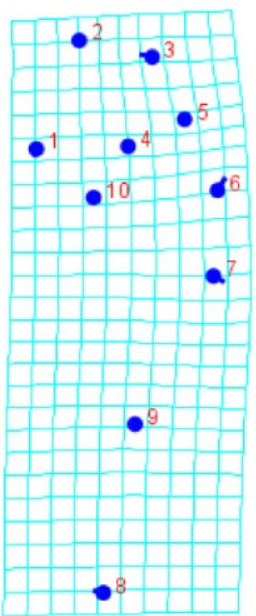

B

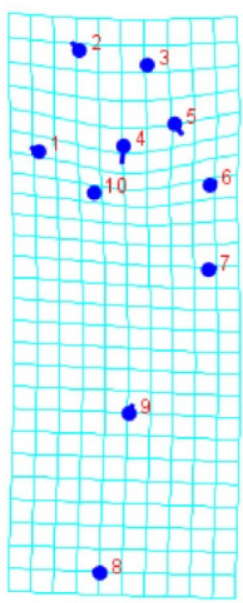

E

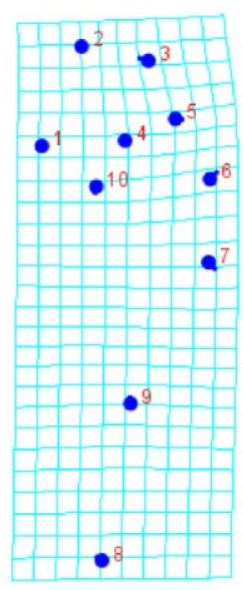

C

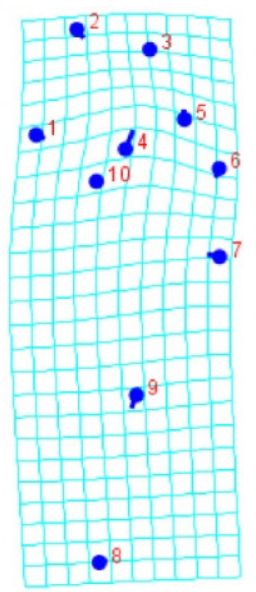

$\mathbf{F}$

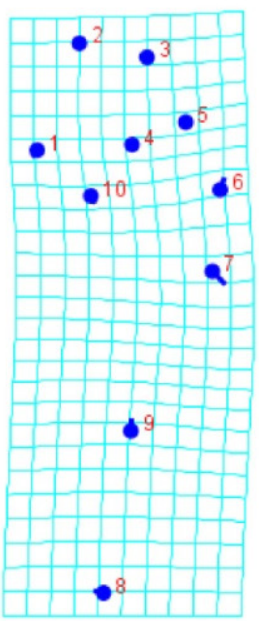

Figure 4. The result of DFA analysis in five ranids. A. Pelophylax bedriagae- $R$. macronemis, B. P. caralitanus $-R$. macrocnemis, C. P. ridibundus - R. macrocnemis, D. Pelophylax bedriagae-R. tavasensis, E. P. caralitanus $-R$. tavasensis, F. P. ridibundus - R. tavasensis. 
The shape differences between $P$. caralitanus and $R$. macrocnemis were as follows: (1) more laterally located and smaller the cornua trabeculae, (2) more anteriorly oriented the articular process of the palatoquadrate, (3) smaller processus muscularis quadrati, (4) smaller the otic capsule. However, the shape differences between $P$. caralitanus and $R$. tavasensis were caused by the more medially oriented and smaller the processus muscularis quadrati, more laterally oriented the cornua trabeculae, more medially located the articular process of the palatoquadrate and more laterally located and smaller the otic capsule (Figures $4 \mathrm{~B}$ and $\mathrm{E}$ ).

The shape differences between $P$. ridibundus and $R$. macrocnemis were as follows: (1) more posteromedially oriented the articular process of the palatoquadrate, (2) more laterally located and larger the processuss muscularis quadrati, (3) more laterally orientated and larger the otic capsule and (4) more medially oriented the cornu trabeculae. However, the shape differences between $P$. ridibundus and $R$. tavasensis were caused by the more medially oriented and smaller the processus muscularis quadrati, and more laterally located and smaller the otic capsule (Figures $4 \mathrm{C}$ and $\mathrm{F}$ ).

\section{DISCUSSION}

This is the first study on differentiations among five ranid species by using geometric morphometrics. We tested the hypothesis that if there are intra- and interspecific differences between Pelophylax sp. and Rana sp.. Although the result of PCA did not show any separation among species, other multivariate analysis showed the separations among species.. The results of multivariate analysis (CVA) showed that the two genera are correctly separated from one another. Rana macrocnemis and $R$. tavasensis are classified as one cluster and three Pelophylax species ( $P$. ridibundus, $P$. bedriagae and $P$. caralitanus) form another cluster. Rana species are distinct from Pelophylax species on the basis of the more lateral orientated and smaller the cornua trabeculae, more anterior orientation of the articular process, a smaller the processus muscularis quadrati and more lateral oriented and smaller the otic capsule. Pelophylax species have closer similarities whereas Rana species significantly differed from one another. Moreover, DFA is an important method to examine the separation between two species. The results of DFA indicated that a high differentiation between the genera Pelophylax and Rana and within the genus Rana.

Intra- and interspecific morphological differences among species are often caused by an interaction between genetic and environmental factors [25]. Species are influenced by these environmental factors during the early developmental stages. However, this variability may not effect species differences at the molecular level [26]. The genus Pelophylax is formerly included in genus Rana and the taxonomic status of the genus Pelophylax is changed by Frost et al. [11]. The genus Pelophylax is the most complicated genus to identified [27]. Different color and patterns of ranids, especially Pelohylax species, exist in the same environment. These morphological variations leave the classification of ranids unclear.

Recently, the number of GMM studies has increased. This method has been used in many taxonomic groups like fish [28], amphibians [15], reptiles [29], mammals [30]. GMM based studies provide more powerful comparison than traditional morphological analyses that based on linear measurement data to discriminate shape variation of species. In this study, we investigated the chondrocranial anatomy in Rana and Pelophylax species and the results indicate that there are three main differences which are related with the larval upper jaw, hyobranchial skeleton and ossification time and sequence between the water (Pelophylax sp.) and mountain (Rana sp.) frogs (Yıldırım., in prep). In this sense, the results of geometric morphometrics are consistent with our unpublished study.

Turkish water frogs are characterized by intraspecific polymorphism in terms of the body size and dorsal color patterns [31]. Thus, molecular and bioacoustic studies are the reason of changing taxonomic status of these frogs $[6,9,32-34]$. GMM 
is important to understand shape variation in amphibians and it is still an open field to provide different perspectives for future studies. I believe our study has provided an important data to address morphometric variation answers of anuran species for further inquiry.

\section{Acknowledgments}

This study was supported by Tübitak (2218 - National Postdoctoral Research Scholarship Programme). I thank to Prof. Dr. Eyup BAŞKALE for his guidance. I am further sincerely grateful to Dr. Tuğba AKKAYA HOCAGiL for improving the English of the text. This research was approved by the Animals Ethics Committee of Pamukkale University (60758568-020/52573) and the General Directorate of Nature Conservation and Natural Parks, Ministry of Forestry and Water Affairs (72784983-488.04 221751).

\section{References}

1. AmphibiaWeb. 2017. 〈https://amphibiaweb.org〉 University of California, Berkeley, CA, USA. Accessed 16 Nov 2017.

2. F.S. Bodenheimer, Introduction into the knowledge of the Amphibia and Reptilia of Turkey, Rev. Fac. Sci. Istanbul Univ., 9 (1944) 1-83.

3. M. Başoğlu, N. Özeti, Amphibians of Turkey. Ege Üniversitesi Fen Fakültesi Kitaplar Serisi, İzmir Türkiye, 1973.

4. D.R. Frost, Amphibian species of the World: A taxonomic and geographic reference, Association of systematic collections and Allen Press Inc, Lawrence, KS, 1985.

5. A. Dobius, Notes sur la classification des Ranidae (Amphibiens, Anoures), Bull. Mens. Soc. Linn., 61 (1992) 305-352.

6. H. Schneider, U. Sinsch, E. Nevo, The lake frogs in Israel represent a new species, Zool. Anz. 228 (1992) 97-106.

7. A. Dubois, A. Ohler, Frogs of the subgenus Pelophylax (Amphibia, Anura, genus Rana): a catalogue of available and valid scientific names, with comments on name-bearing types, complete synonymies, proposed common names, and maps showing all type localities, Zool. Polon., 39 (1995) 139-204.

8. U. Sinsch, H. Schneider, Taxonomic reassessment of Middle Eastern water frogs: Morphological variation among populations considered as Rana ridibunda, $R$ bedriagae or R. levantina, J. Zool. Syst. Evol. Res., 37 (1999) 67-73.

9. T. Jdeidi, C. Bilgin, A. Kence, New localities extend the range of Rana bedriagae caralitana Arıkan, 1988 (Anura: Ranidae) further west and suggest specific status, Turk. J. Zool., 25 (2001) 153-158.

10. D.M. Hillis, T.P. Wilcox, Phylogeny of the new World true fogs (Rana), Mol. Phylogenet. Evol., 34 (2005) 299-314.

11. D.R. Frost, T. Grant, J.N. Faivovich, R.H. Bain, A. Haas, C.F.B. Haddad, R.O. Desa, A. Channing, M. Wilkinson S.C. Donnellan, C.J. Raxworthy, J.A. Campbell, B.L. Blotto, P. Moler, R.C. Drewens, R.A. Nussbaum, J.D. Lynch, D.M. Green, W.C. Wheeler The amphibian tree of life, B. Am. Mus. Nat. Hist., 297 (2006) 1-370.
12. J. Che, J. Pang, H. Zhao, G.F. Wu, E.M. Zhao, Y.P. Zhang, Phylogeny of Raninae (Anura: Ranidae) inferred from mitochondrial and nuclear sequences, Mol. Phylogenet. Evol., 43(2007) 1-13.

13. Z.H. Huang, F.Y. Tu, Characterization and evolution of the mitochondrial DNA control region in Ranidae and their phylogenetic relationship, Gen. Mol. Res., 15(2016) gmr.15038491.

14. P.M. Larson, Chondrocranial development in Iarval Rana sylvatica (Anura: Ranidae): a morphometric analysis of cranial allometry and ontogenetic shape change, J. Morphol., 252 (2002) 131-144.

15. P.M. Larson, Ontogeny, phylogeny, and morphology in anuran larvae: a morphometric analysis of crania development and evolution in Rana larvae (Anura: Ranidae), J. Morphol., 264 (2005) 34-52.

16. R. Vega-Trejo, J.J. Zuniga-Vega, R.B. Langerhans, Morphological differentiation among populations of Rhinella marina (Amphibia: Anura) in western Mexico, Evol. Ecol., 28 (2013) 69-88.

17. E. Yıldırım, U. Kaya, Chondrocranial differences in Bufotes variabilis (Anura: Bufonidae): geometric morphometric comparison with two anuran species, Turk. J. Zool., 41(2017) 241-249.

18. M. Singleto, Patterns of cranial shape variation in the Papionini (Primates: Cercopithecinae), J. Hum. Evol., 42 (2002) 547-578.

19. M.L., Zelditch, J. Mezey, D.H. Sheets, B. Lundrigan, T. Garland, Developmental regulation of skull morphology II. Ontogenetic dynamics of covariance. Evol. Dev. 8 (2006) 46-60.

20. C. Costa, C. Angelini, M. Scardi, P. Menesatti, C. Utzeri, Using image analysis on the ventral colour pattern in Salamandrina perspicillata (Amphibia: Salamandridae) to discriminate among populations, Biol. J. Linn. Soc., 96(2009) 35-43

21. F.L. Bookstein (1996). Standard formula for the uniform shape component in landmark data. In: Marcus, LF, Corti M, Loy A, Naylor G, Slice DE, editors. Advances in morphometrics.Proceedings of the 1993 NATO Advanced Studies Institute on Morphometrics in II Ciocco, Italy. New York: Plenum. pp 153-168.

22. The IUCN Red List of Threatened Species. Version 2017-3. 〈www.iucnredlist.org〉. Downloaded on 18 December 2017.

23. K.L. Gosner, A simplified table for staging anuran embryos and larvae with notes on identification, Herpetologica, 16 (1960) 183-190.

24. R. Wassersug (1976). Oral Morphology of Anuran Larvae: Terminology and General Description. Occasional Paper 48 of the Museum of Natural History. Lawrence, KS, USA: University of Kansas.

25. W.C. Clark, The environment and the genotype in polymorphism. Zool. J. Linn. Soc., 58 (1976) 255-262.

26. S. Tudela Morphological variability in a Mediterranean, genetically homogeneous population of the European anchovy, Engraulis encrasicolus, Fisheries Res., 42 (1999) 229-243.

27. J.M. Thirion, P. Evrard (2012). Guide des reptiles et amphibiens de France. Editions Berlin, Paris.

28. H. Mousavi-Sabet, H. Anvarifar Landmark-based morphometric variation between Cobitis keyvani and Cobitis faridpaki (Pisces: Cobitidae), with new habitat for $C$. faridpaki in the southern Caspian Sea basin, Folia Zool., 62 (2013) 167-175. 
29. A. Kaliontzopoulou, M.A. Carretero, G.A. Llorente Head shape allometry and proximate causes of head sexual dimorphism in Podarcis lizards: joining linear and geometric morphometrics, Biol. J. Linn. Soc., 93 (2008) 111-124.

30. A. Cardini D. Nagorsen, P. O'Higgins, P.D. Polly, R.W. Thorington, P. Tongiorgi, Detecting biological distinctiveness using geometric morphometrics: an example case from the Vancouver Island marmot, Eth. Ecol. Evol., 21 (2009) 209-223.

31. A. Manukyan A (2002). The comparative characteristic of the some morphometric features of the Rana ridibunda Pall. Diploma Thesis, Yerevan State Pedagogical Univ. Yerevan. 20 p.
32. P. Beerli, H. Hotz, T. Uzzell, Geologically dated sea barriers calibrate a protein clock for Aegean water frogs, Evol., 50 (1996) 1676-1687.

33. J. Plotner, T. Ohst, W. Böhme, R. Schreiber, Divergence in mitochondrial DNA of Near Eastern water frogs with special reference to the systematic status of Cypriote and Anatolian populations (Anura, Ranidae), AmphibiaReptilia, 22 (2001) 397-412.

34. J. Plotner, T. Uzzell, P. Beerli, C. Spolsky, T. Ohst, S.N. Litvinchuk, G.D. Guex, H.U. Reyer, H. Hotz, Widespread unidirectional transfer of mitochondrial DNA: a case in western Palaearctic waterfrogs, J. Evol. Biol., 21 (2008) 668-681. 
